\title{
MANAJEMEN SUMBER DAYA MANUSIA DI UD KUDA MASS DALAM MENINGKATKAN KINERJA KARYAWAN
}

\author{
M. Zikwan, A. Muhyiddin Khotib \\ ziksaririzik@gmail.com, muhyiddin.mu67@gmail.com \\ Fakultas Syariah dan Ekonomi Islam Universitas Ibrahimy Situbondo
}

\begin{abstract}
ABSTRAK
Human Resources is one of the resources contained in the organization, including all people who carry out activities. In general, the resources contained in the organization can be grouped into two types, Human Resources, Resources. Included in this non-human resource group include capital, machinery, technology, materials. UD Kuda Mass Turen Malang is a UD which operates in the Macaroni sector, in its role as one of the driving wheels of the economy in the village of Reject Turen Malang UD Kuda mass was exposed to UD who maintained Islamic ethics, in the sense that UD Kuda Mass did not only work for the world alone. however, the application of the responsibility of a Muslim is also carried out at the UD. In his duties as an entrepreneur that combines the world and the hereafter.
\end{abstract}

Keywords: Manajemen Sumber Daya Manusia, Kinerja Keryawan.

\section{PENDAHULUAN}

Dalam Pembukaan Undang-Undang Dasar 1945, antara lain disebutkan bahwa pemerintahan negara dibentuk "untuk memajukan kesejahteraan umum". Banyak ukuran yang dapat digunakan untuk mengukur kesejahteraan umum. Lapangan kerja merupakan salah satu ukuran utama yang dapat dan perlu dimanfaatkan. Lapangan kerja produktif yang mencukupi merupakan sarana utama bagi masyarakat untuk memperoleh pendapatan dengan halal. Lapangan kerja menyangkut harga diri, dan pengangguran yang berkepanjangan akan berarti hilangnya harga diri selain dari menurunnya tingkat hidup bagi yang bersangkutan.

Negara kita Indonesia tidak membatasi warga negaranya untuk berwirausaha, justru sangat mendukung berkembangnya entrepreneur dengan kebijakan pemerintah yang membuka peminjaman skala mikro atau makro pada bank-bank milik BUMN. Negara Indonesia termasuk negara yang mayoritas penduduknya beragama Islam, 
sehingga setiap aktifitas yang dilakukan oleh masyarakat indonesia tidak boleh terlepas dari tuntunan agama Islam. Termasuk yang harus berada dibawah tuntunan Islam adala kegiatan dibidang sektor perekonomian.

Tidak dapat dipungkiri oleh siapapun yang berfikir jernih dan logis, bahwa Islam merupakan suatu sistem hidup, suatu pedoman hidup way of life (Eko Suprayitno, 2005) Hal ini dapat dibuktikan dari sistem ajaran islam yang bersifat komprehensif dan universal. Islam sebagai agama Allah yang sempurna memberikan petunjuk kepada manusia tentang bidang usaha yang halal, cara berusaha, dan bagaimana manusia harus mengatur hubungan kerja dengan sesama mereka supaya memberikan manfaat yang baik bagi kepentingan bersama dan dapat menciptakan kesejahteraan serta kemakmuran hidup bagi segenap manusia. Islam tidak hanya menyuruh manusia bekerja bagi kepentingan dirinya sendiri secara halal, tetapi juga memerintahkan manusia menjalin hubungan kerja dengan orang lain bagi kepentingan dan keuntungan kehidupan manusia di jagat raya ini. Oleh karena itu, dalam bidang usaha dan wiraswasta Islam benar-benar memberikan petunjuk-petunjuk yang jelas untuk dapat dijadikan pedoman melakukan usaha dan wiraswasta yang baik.

Dalam islam, berdagang atau bisnis atau wirausaha sangat dianjurkan, karena nabi kita pun seorang wirausahawan. Ada suatu nilai yang terkandung dalam islam terkait wirausaha, yakni jujur dan amanah serta berbisnislah yang wajar dan tidak melampaui batas. Islam sendiri menganjurkan umatnya untuk menjadi kaya. Maka dari itu dengan berwirausaha menurut risalah nabi muhammad SAW berarti kita mencintai suri tauladan kita.

Nabi Muhammad SAW sudah berbisnis kecil-kecilan pada usia kurang dari 12 tahun (jauh sebelum menjadi Rasul) dengan cara membeli barang dari suatu pasar dan kemudian menjualnya kepada orang lain dengan maksud memperoleh keuntungan. Aktivitas bisnis tersebut dilakukan dengan maksud untuk meringankan beban pamannya Abu Thalib. Dalam usahanya tersebut, beliau bersama dengan pamannya Abu Thalib juga pernah melakukan pejalanan dagang ke Syiria. Bisnis nabi Muhammad SAW terus berkembang sampai kemudian Khadijah menawarkan kemitraan bisnis dengan sistem profit sharing. Selama bermitra dengan Khadijah, nabi Muhammad SAW telah melakukan pejalanan ke pusat bisnis di Habasyah (Ethopia), Syria dan Jorash. 
Setelah menikah dengan Khadijah, usaha dagangnya tetap berjalan dengan bertindak sebagai manajer sekaligus mitra usaha istrinya.

Wirausaha berasal dari kata "wira" gagah berani, perkasa dan "usaha". (Abdul Jalil, 2013) Wirausaha adalah kegiatan yang dilakukan oleh perorangan atau kelompok orang dengan melihat peluang yang ada, kemudian membuka usaha dalam bidang produksi atau distribusi barang ekonomi atau jasa, memelihara dan membesarkannya dengan mencurahkan pikiran, waktu dan tenaganya dengan maksud untuk memperoleh keuntungan.

Wirausaha adalah seorang pembuat keputusan yang membantu terbentuknya sistem ekonomi perusahaan yang bebas. Sebagaian besar pendorong perubahan, inovasi, dan kemajuan di perkonomian kita akan datang dari para wirausaha; orang-orang yang memiliki kemampuan untuk mengambil reasiko dan mempercepat pertumbuhan ekonomi. (Justin G. Longenecker \& dkk, 2001)

kewirausahaan adalah hal-hal atau upaya-upaya yang berkaitan dengan penciptaan kegiatan atau usaha atau aktivitas bisnis atas dasar kemauannya sendiri dan mendirikan usaha atau bisnis dengan kemauan dan kemampuan sendiri. (Leonardus Saiman, 2009)

Islam memang tidak memberikan penjelasan secara eksplisit terkait konsep tentang kewirausahaan (enterpreneurship) ini, namun diantara keduanya mempunyai kaitan yang cukup erat, memiliki ruh atau jiwa yang sangat dekat, meskipun bahasa teknis yang digunakan berbeda. Dalam islam digunakan istilah kerja keras, kemandirian (biyadihi) dan tidak mudah menyerah, setidaknya terdapat beberapa ayat al-Quran maupun hadist yang dapat menjadi rujukan pesan tentang semangat kerja keras dan kemandirian ini, seperti:

Ada beberapa rambu-rambu yang harus diperhatikan dalam berwirausaha diantaranya, beriwara uasaha tidak boleh meninggalkan kegiatan ibadah, sebagaimana telah tertera didalam al-quran

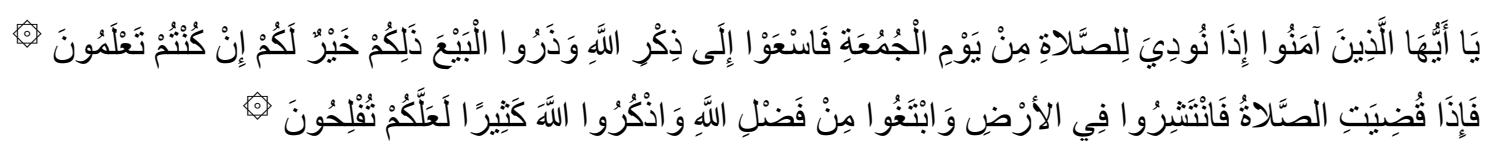

Artinya: Hai orang-orang beriman, apabila diseru untuk menunaikan shalat Jum'at, Maka bersegeralah kamu kepada mengingat Allah dan tinggalkanlah jual beli yang demikian itu lebih baik bagimu jika kamu mengetahui. Apabila 
telah ditunaikan shalat, Maka bertebaranlah kamu di muka bumi; dan carilah karunia Allah dan ingatlah Allah banyak-banyak supaya kamu beruntung.

UD Kuda Mass Turen Malang termasuk jenis wirausaha yang bergerak dibidang usaha makanan ringan atau makaroni. Usaha yang dirintis oleh ibu Mutrifah pada tahun 1984 kini telah berkembang pesat. Hingga pada awal $2004 \mathrm{Hj}$ Mutrifah sudah tidak mengelola UD Kuda Mass tersebut, akan tetapi UD kuda Mass yang sudah berkembang diserahkan kepada anak-anaknya. Perkembangan UD Kuda Mass tidak lepas dari manajemen sumber daya manusia yang handal. Hingga saat ini UD Kuda Mass terus mengikuti perkembangan

Dalam penelitian ini peneliti akan memaparkan tentang manajemen sumber daya manusia di UD Kuda Mass dalam meningkatkan kinerja karyawan yang bertujuan untuk mengetahui bagaimana penerapan manajemen sumber daya manusia di UD Kuda Mass dalam meningkatkan kinerja karyawannya, serta menjadi rujukan bagi peneliti lainnya dalam pembahasan manajemen sumber daya manusia dalam berwirausaha.

\section{KAJIAN TEORI}

\section{Pengertian Wirausaha}

Dalam perjalanan wirausaha terdapat beberapa istilah mengenai wirausaha, dimulai dengan istilah wiraswasta, wirausaha dan enterpreneurship. Pada dasarnya istilah-istilah ini merupakan suatu kesatuan, namun dalam perjalanannya ketiga istilah ini memiliki beragam macam pengertian. Dalam praktiknya istilah wiraswasta sering dipakai tumpang tindih dengan istilah wirausaha. Didalam berbagai literatur dapat dilihat bahwa pengertian wiraswasta sama dengan wirausaha, demikian pula dengan penggunaan wirausaha sama dengan wiraswasta.

Wiraswasta terdiri dari tiga kata: wira, swa dan sta, wira berarti manusia unggul, teladan, berbudi luhur, berjiwa besar, berani, pahlawan atau pendekar kemajuan dan memiliki keagungan watak, swa artinya sendiri, sementara sta adalah berdiri. Dari pengertian harpiah ini dapan diambil kesimpulan bahwa wiraswasta adalah manusia teladan yang berjiwa besar serta gagah berani yang mampu berdiri sendiri. Namun menurut prof Dr. Haryati Subadio wirausaha adalah manusia teladan yang berbudi luhur yaitu manusia yang mampu berdiri atas kemampuan sendiri (Buchori Alma, tt) Jadi 
seorang wiraswasta adalah usahawan yang disamping mampu berusaha dalam bidang ekonomi umumnya dan niaga khususnya secara tepat guna juga berwatak merdeka lahir batin serta budi luhur. Dengan demikian seorang wiraswasta tidak akan menjadi "economic animal".

Wirausaha berasal dari kata "wira" artinya hero atau pahlawan. dan "usaha". Jadi wira usaha adalah usaha yang digerakkan oleh modal semangat keberanian dan kejujuran. Wirausaha merupakan kegiatan yang dilakukan oleh perorangan atau kelompok orang dengan melihat peluang yang ada, kemudian membuka usaha dalam bidang produksi atau distribusi barang ekonomi atau jasa, memelihara dan membesarkannya dengan mencurahkan pikiran, waktu dan tenaganya dengan maksud untuk memperoleh keuntungan. Dalam definisi ini ditekankan bahwa seorang wirausaha adalah orang yang melihat adanya peluang kemudian menciptakan sebuah organisasi untuk memamfaatkan peluang tersebut. Wirausaha adalah seorang pembuat keputusan yang membantu terbentuknya sistem ekonomi perusahaan yang bebas. Sebagaian besar pendorong perubahan, inovasi, dan kemajuan di perkonomian kita akan datang dari para wirausaha; orang-orang yang memiliki kemampuan untuk mengambil reasiko dan mempercepat pertumbuhan ekonomi. (Leonardus Saiman, 2009)

\section{Wirausaha Dalam Islam}

Islam memang tidak memberikan penjelasan secara eksplisit terkait konsep tentang kewirausahaan (entrepreneurship) ini, namun di antara keduanya mempunyai kaitan yang cukup erat, memiliki ruh atau jiwa yang sangat dekat, meskipun bahasa teknis yang digunakan berbeda. Dalam Islam digunakan istilah kerja seperti al-'amal, al-kasb, al-fi'l, as-sa'yu, an-nasru, ash-sha'n, dan kemandirian (biyadihi). (Abdul Jalil, 2013) Meskipun masing-masing kata mempunyai makna dan implikasi yang berbeda, namun secara umum rententan kata-kata tersebut memiliki makna pekerjaan, berusaha dan mencari rezeki.

\section{Pengertian SDM}

Sumber Daya Manusia merupakan salah satu sumber daya yang terdapat dalam organisasi, meliputi semua orang yang melakukan aktifitas. Secara umum, sumber daya yang terdapat dalam organisasi bisa dikelompokkan atas dua macam yakni, Sumber Daya Manusia/Human Resource, Sumber Daya Non Manusia/Non-Human Resource. 
Yang termasuk dalam kelompok sumber daya non manusia ini antara lain modal, mesin, teknologi, bahan-bahan (material), dan lain-lain. (Faustino Cardoso Gomes, 1995)

Sumber daya manusia adalah kemampuan terpadu dari daya pikir dan daya fisik yang dimiliki individu. Pikiran dan sifatnya ditentukan oleh keturunan dan lingkungannya, sedangkan prestasi kerjanya di motivasi oleh keinginan untuk memenuhi kepuasannya. (Malayu S.P Hasibuan, 2007) Pada dasarnya sumber daya manusia adalah kekuatan daya pikir dan berkaya manusia yang masih tersimpan dalam dirinya yang perlu dibina dan digali serta dikembangkan untuk dimanfaatkan sebaikbaiknya bagi kesejahteraan kehidupan manusia.

Semula SDM merupakan terjemahan dari "human resources", namun ada pula ahli yang menyamakan sumber daya manusia dengan "manpower" (tenaga kerja). Bahkan sebagian orang menyetarakan pengertian sumberdaya manusia dengan personal (personalia, kepegawaian dan sebagainya). (Edy Sutrisno, $\mathrm{tt}$ )

Pada dasarnya sumber daya manusia merupakan salah satu sumber yang sangat dibutuhkan oleh setiap organisasi. Sebab SDM merupakan tonggak dasar dalam subuah organisasi atau instansi untuk mencapai visi dan misinya.

\section{Pengembangan Kualitas SDM}

Potensi manusia yang nantinya ditunjukkan dalam aspek yang salah satunya adalah kualitas, hanya dapat dicapai dengan adanya pengembangan sumber daya manusia. Hal tersebut diperlukan karena sumber daya manusia merupakan faktor yang paling mempengaruhi kehidupan. Kemampuan manusia untuk mempengaruhi alamnya menunjukkan bahwa posisi sumber daya manusia sangat sentral adanya. Pengembangan sumber daya manusia berkaitan dengan tersedianya kesempatan dan pengembangan belajar, membuat program-program training yang meliputi perencanaan, penyelenggaraan, dan evaluasi atas program-program tersebut. (Michael Amstrong, 1994)

Pengembangan sumber daya manusia dapat didefinisikan sebagai seperangkat aktivitas yang sistematis dan terencana yang dirancang dalam memfasilitasi para pegawainya dengan kecakapan yang dibutuhkan untuk memenuhi tuntutan pekerjaan, baik pada saat ini maupun masa yang akan datang. (Desimone RL, Werner JM \& Harris DM, 2001) Pengembangan sumber daya manusia adalah suatu usaha yang terencana dan berkelanjutan yang dilakukan oleh organisasi dalam meningkatkan kompetensi 
pegawai dan kinerja organisasi melalui program-program pelatihan, pendidikan, dan pengembangan.

Dari beberapa pengertian di atas, dapat dikatakan bahwa pengembangan sumber daya manusia adalah segala aktivitas yang dilakukan oleh organisasi dalam memfasilitasi pegawai agar memiliki pengetahuan, keahlian, dan atau sikap yang dibutuhkan dalam menangani pekerjaan saat ini atau yang akan datang. Aktivitas yang dimaksud, tidak hanya pada aspek pendidikan dan pelatihan saja, akan tetapi menyangkut aspek karier dan pengembangan organisasi. Dengan kata lain, pengembangan sumber daya manusia berkaitan erat dengan upaya meningkatkan pengetahuan, kemampuan, dan atau sikap anggota organisasi serta penyediaan jalur karier yang didukung oleh fleksibilitas organisasi dalam mencapai tujuan organisasi.

Sedangkan tujuan pengembangan sumber daya manusia adalah untuk memastikan bahwa organisasi mempunyai orang orang yang berkualitas untuk mencapai tujuan organisasi untuk meningkatkan kinerja dan pertumbuhan Tujuan tersebut di atas dapat dicapai dengan memastikan bahwa setiap orang dalam organisasi mempunyai pengetahuan dan keahlian dalam mencapai tingkat kemampuan yang dibutuhkan untuk melaksanakan pekerjaaan mereka secara efektif.

\section{Metode pengembangan SDM}

Metode Pelatihan Dan Pengembangan Menurut Murti Sumarni dan John Soeprihanto, ada dua metode latihan dan pendidikan, yaitu: (Murti Sumarni dan Jonh Soeprihanto, 2000)

\section{Latihan (Training)}

Latihan adalah suatu kegiatan untuk memperbaiki kemampuan seorang karyawan dengan cara meningkatkan kemampuan dan ketrampilan karyawan.

\section{Pendidikan (Education)}

Pendidikan adalah latihan untuk memperbaiki latihan seorang karyawan tentang pengetahuan umum dan pengetahuan ekonomi pada umumnya, termasuk peningkatan penguasaan teori dan ketrampilan mengambil keputusan dalam menghadapi persoalan persoalan organisasi perusahaan.

Program-program latihan dan pengembangan dirancang untuk meningkatkan prestasi kerja, mengurangi absensi dan perputaran, serta memperbaiki kepuasan kerja. Ada dua kategori pokok program latihan dan pengembangan, yaitu: 


\section{Metode Praktis (on the job training)}

Teknik-teknik on the job training merupakan metode latihan yang paling banyak digunakan. Latihan dengan menggunakan metode ini dilakukan di tempat kerja. Karyawan dilatih tentang pekerjaan baru dengan supervisi langsung seorang pelatih yang berpengalaman. Metode latihan ini sangat ekonomis, karena tidak perlu membiayai para trainers dan trainee, tidak perlu menyediakan peralatan dan ruang khusus.

\section{Pembekalan (Coaching)}

Coaching adalah bentuk pelatihan dan pengembangan yang dilakukan di tempat kerja oleh atasan dengan membimbing petugas melakukan pekerjaan secara informal dan biasanya tidak terencana, misalnya bagaimana melakukan pekerjaan, bagaimana memecahkan masalah.

\section{Magang (Apprenticeship)}

Apprenticeship adalah pelatihan yang mengkombinasikan antara pelajaran di kelas dengan praktek di lapangan, yaitu setelah sejumlah teori diberikan kepada peserta, peserta dibawa praktek ke lapangan.

6. Latihan Instruksi Jabatan (Job Instruction Training)

Job instruction training adalah pelatihan dimana ditentukan seseorang bertindak sebagai pelatih untuk menginstruksikan bagaimana melakukan pekerjaan tertentu dalam proses kerja.

7. Teknik-teknik presentasi informasi dan metode-metode simulasi (off the job traning)

Pendidikan atau pelatihan dengan menggunakan metode ini berarti karyawan sebagai peserta diklat, ke luar sementara dari kegiatan atau pekerjaannya. Kemudian mengikuti pendidikan atau pelatihan, dengan menggunakan teknik-teknik belajar mengajar seperti lazimnya. Ada beberapa jenis metode off the job training, diantarnya yaitu: Lectures (kuliah) Presetasi atau ceramah yang diberikan oleh pelatih atau sekelompok pendengar, biasanya kelompok yang cukup besar. (Maihot Tua Effendi, 2002)

\section{METODE PENELITIAN}

Pendekatan penelitian ini menggunakan pendekatan kualitatif, karena permasalahan yang akan diteliti belum jelas, holistic, kompleks, dinamis dan penuh makna. (Sugiono, 2011) Metode penelitian kualitatif juga dapat diartikan sebagai 
metode penelitian yang berlandaskan pada filsafat Postpositivisme, digunakan untuk meneliti objek alamiah. Dimana peneliti adalah instrument kunci. (Sugiono, 2012) Dengan kata lain bahwa penelitian kualitatif, yaitu suatu prosedur penelitian yang mendiskripsikan prilaku orang, tempat, atau peristiwa tertentu sacara rinci dan mendalam.

Pengumpulan data peneliti lakukan dengan cara observasi, wawancara dan dokumentasi. Dalam penelitian kualitatif, data diperoleh dari berbagai sumber, dengan menggunakan teknik pengumpulan data yang bermacam-macam dan dilakukan secara terus-menerus. Aktifitas dalam analisis data yaitu: data reduction, data display dan conclusion drawing/ verification.

Untuk menguji keabsahan data yang telah dikumpulkan, maka peneliti menggunakan metode pengujian kebsahaan data dengan teknik triangulasi dimana trigulasi diartikan sebagai pengecekan data dari berbagai sumber dengan berbagai cara dan berbagai waktu.

\section{HASIL DAN PEMBAHASAN}

UD Kuda Mass Turen Malang merupakan sebuah UD yang bergerak di bidang Makaroni, dalam peranannya sebagai salah satu roda penggerak perekonomian di desa Tolak Turen Malang UD Kuda mass terkenal dengan UD yang menjaga etika ke Islaman, untuk menjaga kelestarian serta kemajuan usahanya maka UD Kuda Mass selalu berusaha untuk meningkatkan kualitas SDM. Ada beberapa langkah yang dilakukan oleh UD Kuda Mass dalam meningkatkan kualitas sumber daya manusia diantaranya sebagai berikut.

\section{Penerapan Manajemen STAF}

STAF merupakan singkatan dari Siddiq, Tabligh, Amanah, dan Fathanah. Dalam kewirausahaan yang dilakukan di UD Kuda Mass Turen Malang, menejar UD tersebut selalu berpatokan kepada manajemen STAF, dimana dalam setiap lini kegiatan dan pekerjan hal ini selalu diutamakan, hal inilah yang menjadi resep UD Kuda Mass dalam mewujudkan sebuah usaha yang islami besar dan tangguh. Sebagi langkah awal Ada dua hal yang harus dilakukan. Pertama, pengelola yang siddiq dan amanah. Kedua, sistem pengelolaan yang tabligh dan fatonah. Kedua hal tersebut, dikembangkan berdasarkan sifat-sifat Nabi Muhammad SAW yang sudah sangat terkenal yaitu siddiq, tabligh, amanah, dan fatonah. Keempat sifat-sifat Nabi SAW tersebut biasa disingkat 
"STAF". Dengan dua hal tersebut menurut penulis UD Kuda Mass sudah menjadi suatu UD yang Islami dalam artia di UD tersebut tidak memisahkan antara urusan dunia dan akhirat sehingga menurut penulis UD Kuda Mass sudah mampu menciptakan lapangan pekerjaan dan yang mampu bersaing dalam mengahadapi persaingan pasar.

Siddiq berarti “jujur”, maka seluruh pengelola UD Kuda Mass mulai dari jajaran pengurus, pengawas, manajer, direktur dan karyawan harus jujur dalam melaksanakan tugasnya. Karena itu, pengelola yang siddiq harus jujur dalam perkataan dan perilakunya, tidak pernah cacat di masyarakat dalam hal keuangan dan menepati janji. Kemudian pengelola yang amanah. Amanah berarti "dapat dipercaya". Pengelola yang amanah berarti pengelola yang: Antara perbuatan dan perkataannya sama. Catatan keuangannya sesuai dengan kenyataan. Pengeluaran dan pemasukan selalu dicatat sesuai dengan ketentuan. Semua janji ditepati dan pelayanan yang cepat dan tepat atas penarikan simpanan anggota. Jadi dengan menerapkan konsep kejujuran dan amanah maka UD Kuda Mass Turen Malang menjadi UD yang tangguh yang siap menghadapi tantangan pasar bebas. Dengan adanya sistem menejer yang mengelola dengan sistem kejujuran ditambah dengan pengelola yang amanah sudah menjadi SDM UD tersebut berkualitas.

Tabligh itu berarti transparansi atau keterbukaan, sedang fatonah itu berati profesional. Pengelolaan yang transparan diwujudkan dalam hubungan baik antara pengelola dan anggota, antara pengelola sendiri dan hubungan dengan Pemerintah. Jadi Dengan adanya pengelola yang transparan dan profesional maka kualitas ketangguhan UD Kuda Mass Turen Malang akan mejadi semakin meningkat.

Dalam praktiknya pengelolaan yang fatonah atau profesional diwujudkan dengan Memiliki Standar Operasional Manajemen (SOM) dan Standar Operasional Prosedur (SOP). Semua pengelola paham SOM dan SOP. Semua pengelola disiplin dalam menerapkan SOM dan SOP sesuai dengan bidangnya. Pengelola yang siddiq dan amanah serta sistem pengelolaan yang tabligh dan fatonah menimbulkan dampak positif yang luar biasa bagi UD Kuda Mass. Sehingga sebagian besar kesuksesan yang sudah atau sedang diraih oleh UD Kuda Mass Turen Malang merupak perwujudan dari sistem menajemen STAF.

\section{Manajamen 3 D}


UD Kuda Mass merupakan salah satu UD yang berperan sebagai jawaban dari kegelisahan ekonomi masyarakat, peran aktif dari UD Kuda Mass akan menjadi solusi terbaik bagi perekonomian masyarakat Ture Malang dan sekitarnya. Oleh karena itu sebagai wujud dari kegiatan pengembangan telah diterapkan beberapa program dalam rangka meningkatkan kualitas Sumber Daya Manusia di UD Kuda Mass, untuk meningkatkan kualitas SDM di UD Kuda Mass, UD Kuda Mass telah melakukan beberapa program yang yang disingkat dengan 3 D (Disiplin Shalat, Disiplin Waktu, Disiplin aturan). Jadi dengan adanya penerpan 3D ini UD Kuda Mass sudah mampu memberikan SDM terbaik sehingga cita-citanya sebagai jawaban dari kegelisahan ekonomi masyarakan benar-benar terwujud. Program 3D tersebut merupakan program inti UD Kuda Mass untuk meningkatkan kualitas UD Kuda Mass.

Dalam kaitanya disiplin shalat, UD menyadari dan meyakini bahwa agama Islam merupakan agama yang kaffah, oleh karena itu disetiap kegiatan Islam selalu hadir. Kewajiban bekerja di UD Kuda Mass tidak mereka pisahkan dari nilai-nilai spritual. Antara dunia dan akhirat, antara Masjid dan pasar, tidak berdiri secara diametral, namun berada dalam formasi keseimbangan antara kepentingan akhirat kepentingan sosial dan ekosistem, dalam hal ini yang menjadi acuan UD kuda Mass adalah firman Allah yang berti: "Dan carilah pada apa yang telah dianugerahkan Allah kepadamu (kebahagiaan) negeri akhirat, dan janganlah kamu melupakan bahagianmu dari (kenikmatan) duniawi dan berbuat baiklah (kepada orang lain) sebagaimana Allah telah berbuat baik, kepadamu, dan janganlah kamu berbuat kerusakan di (muka) bumi. Sesungguhnya Allah tidak menyukai orang-orang yang berbuat kerusakan.

Oleh karena itulah di UD Kuda Mass diterapkan aturan disiplin shalat, dengan adanya disiplin shalat waktu bekerja menjadi lebih efektif dan maksimal. Dalam dari pada itu terkait dengan konteks disiplin shalat UD Kuda Mass juga mengacu kepada hadist nabi yang berati: "bekerjalah untuk kepentingan duniamu seakan-akan kamu hidup selamanya, dan berbuatlah untuk akhiratmu seakan-akan kamu akan meninggal esok hari".

Menurut peneliti, disiplin shalat yang sudah diterapkan di UD Kuda Mass sudah menjadi media pembelajaran bagi para karyawan dalam memanfaatkan waktu sebaikbaiknya. Hal ini berdasarkan kegiatan ibadah yang diterapkan di UD Kuda Mass dengan menerapkan program disiplin shalat. Dalam hal disiplin shalat UD Kuda Mass 
mewajibkan shalat berjama'ah setiap waktu bagi karyawan yang berada di lokasi pekerjaan dan dilanjutkan dengan gerak batin (riadhah).

Diterapkanya aturan wajib jama'ah adalah bentuk dari peningkatan SDM UD Kuda Mass, sebab dengan dengan aturan ini, etos kerja UD Kuda Mass semakin manjadi teratur dan terarah yang kemudian akan menjadi lebih kompak karena sudah dilatih dengan shalat. Sebagai bentuk kegiatan disiplin shalat yang lain UD Kuda Mass mensunahkan shalat duha berjama'ah bagi karyawan yang bertugas dilokasi UD Kuda Mass sementara untuk karyawan yang terjun dilapangan disunahkan untuk shalat duha sendiri-sendiri. Oleh sebab itu peneliti memberikan kesimpulan bahwa kedisiplinan dan kesuksesan UD Kuda Mass bersumber dari SDMnya yang sudah berkualitas yang selama ini didik dengan menggunakan menajemen yang Islami. Adanya pengaruh ibadah dan dzikir menjadikan etos kerja bagi karyawan UD kuda mass lebih berkualitas.

Bagi UD Kuda Mass disiplin waktu merupakan hal yang urgensi. Hal ini merupakan salah satu peran UD Kuda Mass dalam meningkatkan kualitas SDM, disiplin waktu yang diterapkan di UD Kuda Mass meliputi jam masuk kerja, kegiatan yang berhubungan dengan tugas-tugas di UD Kuda Mass seperti rapat dan lain sebagainya. Dalam hal jam masuk kantor para karyawan diwajibkan tepat waktu, para karyawan UD Kuda Mass hanya memiliki waktu wajib selama delapan jam. Setelah itu para karyawan diberikan kebebasan untuk meneruskan pekerjaanya ataupun tidak. Oleh karen itu, bagi UD Kuda Mass untuk menjadi instansi yang hebat haruslah memamfaatkan waktu semaksimal mungkin. Dengan adanya displin waktu tersebut seluruh kegiatan yang ada di UD Kuda Mass terlaksana sesua perencanaan sehingga pekerjaan yang dapat terselesaikan dengan baik dan berkualitas. Karena itu untuk menumbuhkan etos kedisiplinan di UD Kuda Mass Turen Malang dibutuhkan manajemen waktu agar kualitas SDMnya dapat meningkat.

Disiplin aturan, dalam hal ini para karyawan diwajibkan mematuhi aturan-aturan yang telah diterapkan oleh UD Kuda Mass Turen Malang terutama aturan yang di terapkan di job diss masing-masing. Bagi UD Kuda Mass disiplin merupakan alat yang digunakan untuk berkomunikasi dengan para karyawan agar mereka bersedia untuk mengubah suatu perilaku serta sebagai suatu upaya untuk meningkatkan kesadaran dan kesediaan seseorang menaati semua peraturan perusahaan dan norma-norma sosial yang berlaku. Disiplin menunjuk kan suatu kondisi atau sikap hormat yang ada pada diri 
karyawan terhadap peraturan dan ketetapan perusahaan. Dengan demikian, bila peraturan atau ketetapan yang ada dalam perusahaan itu diabaikan atau sering dilanggar, maka karyawan mempunyai disiplin kerja yang buruk. Disiplin yang baik mencerminkan besarnya tanggungjawab seseorang terhadap tugas-tugas yang diberikan kepadanya. Hal ini mendorong gairah kerja, semangat kerja, dan terwujudnya tujuan UD Kuda Mass Turen Malang.

Melalui program 3D akan mencerminkan kekuatan, karena biasanya seseorang yang berhasil dalam karyanya adalah mereka yang memilki disiplin tinggi. Guna mewujudkan tujuan perusahaan, yang pertama harus segera dibangun dan diteggakan diperusahaan tersebut adalah kedisiplinan atasan dan karyawannya. Jadi menurut peneliti kedisiplinan merupakan kunci keberhasilan UD Kuda Mass Turen Malang dalam mencapai tujuan. Dengan program 3D UD Kuda Mass Turen Malang menjadi terbentengi dari pesaing-pesaing yang akan datang.

\section{pengembangan Sumber Daya Manusia di UD Kuda Mass}

Salah satu strategi UD Kuda Mass Turen Malang dalam meningkatkan pengembangan kinerja SDM karyawan dengan melakukan rapat. Rapat (conference atau meeting) merupakan alat atau media komunikasi kelompok yang bersifat tatap muka dan sangat penting, diselenggarakan oleh banyak organisasi, baik swasta maupun pemerintah termasuk UD Kuda Mass Turen Malang untuk mendapatkan mufakat melalui musyawarah untuk pengambilan keputusan. Jadi rapat merupakan bentuk komunikasi yang dihadiri oleh beberapa orang untuk membicarakan dan memecahkan permasalahan tertentu, dimana melalui rapat berbagai permasalahan dapat dipecahkan dan berbagai kebijaksanaan organisasi dapat dirumuskan. Di UD Kuda Mass Turen Malang menerapkan beberapa rapat diantaranya syahriah (bulanan). Disamping rapat, dalam meningkatkan SDM UD Kuda Mass Turen Malang, UD Kuda Mass Turen Malang juga melakukan pelatihan-platihan dan peningkatan spritualitas keagamaan. Jadi dengan melakukan kegiatan tersebut dapat meningkatkan kinerja para karyawan UD Kuda Mass Turen Malang sehingga UD Kuda Mass Turen Malang menjadi UD yang sukses secara manajemen.

1. Rapat Syahriah (bulanan)

Rapat syahriah (bulanan) dilakukan tiap bulan satu kali yang dihadiri oleh internal UD Kuda Mass Turen Malang, dalam rapat ini para karyawan diberi 
motivasi agas senantiasa meningkatkan kualitas kerjanya. Disamping pemberian motivasi dalam acara rapat syahriah (bulanan) juga dilakukan kontroling terhadap kinerja para karyawan. Hal ini dilakukan agar kinerja UD Kuda Mass Turen Malang menjadi terarah dan terfokuskan pada tugas-tugasnya. Bentuk pemberian motivasi yaitu pemberian semangat, dorongan berupa penyuluhan atau pembinaan tentang penyadaran bahwa karyawan merupakan subjek dalam perusahaan. Jadi dengan adanya pengembangan SDM melalu rapat, kualitas SDM dapat terjaga dan terkontrol oleh UD kuda Mass.

2. Pelatihan

Latihan dan pengembangan karyawan (SDM) adalah usaha yang terencana dari UD Kuda Mass untuk meningkatkan pengetahauan, keterampilan, dan kemampuan karyawan. Pelatihan lebih berorientasi pada peningkatan kemampuan untuk melakukan pekerjaan yang spesifik, dan pengembangan lebih ditekankan untuk melakukan pekerjaan pada masa yan akan datang. Alasan dilakukannya pelatihan dan pengembangan dapat meliputi: karyawan yang direkrut belum dapat melakukan pekerjaan dengan baik, adanya perubahan-perubahan dalam lingkungan kerja, untuk meningkatkan produktivitas, dan menyesuaikan dengan peraturan.

Sebagai langkah strategi peningkatan kinerja karyawan, UD Kuda Mass Turen Malang melakukan program diklat (pendidikan dan pelatihan). Perusahaan memberikan kesempatan kepada pegawai dan menyediakan sarana untuk pengembangan pengetahuan, ketrampilan, perilaku, wawasan, kemampuan manajerial, kepemimpinan melalui program pelatihan dan pendidikan yang diselenggarakan di dalam maupun di luar UD Kuda Mass Turen Malang.

Pelatihan yang diberikan berupa pelatihan yang berkenaan dengan pemasaran maupun pelatihan yang berupa servis exelant yaitu pelayanan yang harus prima terhadap anggota, Dengan adanya pelatihan yang dilakukan di UD Kuda Mass mampu meningkatkan kualitas SDMnya. Pelatihan ini dilakukan dalam rangka menambah wawasan dan untuk meningkatkan kinerja karyawan UD Kuda Mass Turen Malang, melalui pelatihan dan pendidikan, para karyawan dituntut untuk mengikuti secara seksama, sehingga setelah pelaksanaan pelatihan para karyawan menjadi karyawan yang berkualitas. Jadi pelatihan yang dilakukan menjadi salah satu ajang penunjang dalam meningkatkan SDM UD Kuda Mass Turen Malang, sehingga 
para karyawan sudah dikenalkan dengan beberapa permasalahan yang sedang berkembang dan diajarkan serta dicarikan solusi untuk menghadapi permasalahan yang sedang berkembang

3. Peningkatan spritualitas

Spritualitas memang lebih berbasis pada pengalaman menemukan makna tanpa harus terikat dengan institusi (agama) tertentu. Namun pengusaha UD Kuda Mass Turen Malang momosisikan spritualitas sebagai bagian dari keberagaman. Mereka meyakini bahwa Islam adalah agama yang kaffah. Adanya beberapa nilai spritualitas yang diterapkan di UD Kuda Mass Turen Malang akan membentuk suatu bimbingan ruhaniah yang dapat diterima oleh para karyawan, sehingga mereka mampu untuk bekerja sesuai dengan tepat waktu dan menjadi karyawan yang berkualitas.

Dengan berbagai kewajiban keagamaan yang dilakukan di UD Kuda mass menjadikan para karyawan faham akan kewajiban dan tugas mereka. Kewajiban mereka sebagai hamba allah adalah beribadah kepada allah sementara tugas mereka sebagi khalifah dimuka bumi adalah sebagai pemimpin dimuka bumi. Jadi antara dunia dan akhirat tidak pernah mereka pisahkan. Dengan adanya hal seperti ini kualitas SDM karyawan sudah benar-benar terjamin, sebab mereka sudah bisa memenej antara kewajiban mereka dan tugas mereka.

\section{KESIMPULAN}

UD Kuda Mass Turen Malang merupak sebuah UD yang bergerak di bidang Makaroni, dalam peranannya sebagai salah satu roda penggerak perekonomian di desa Tolak Turen Malang UD Kuda mass terkenal dengan UD yang menjaga etika keIslaman, dalam artian di UD Kuda Mass tidak hanya bekerja untuk dunia semata akan tetapi penerapan kewajiaban seorang muslim juga dilakukan di UD tersebut. Dalam rangka meningkatkan kualitas SDM UD Kuda Mass Turen Malang, ada beberapa kgiatan yang dilakukan oleh UD tersebut. Adapun peningkatan kualitas SDM dilakukan dengan beberapa cara diantaranya adalah: menerapkan menajeman STAF, melakun program 3D (disiplin shalat, disiplin waktu dan disiplin aturan.) disamping itu juga dilakukan beberapa kegiatan penunjang seperti rapat pelatihan dan pendidikan serta peningkatan kualitas spritualitasnya 


\section{DAFTAR PUSTAKA}

Abdul Jalil. (2013). Spritual Enterpreneurship Transformasi Spritualitas Kewirausahawan. Yogyakarta: Lkis.

Desimone RL, Werner JM \& Harris DM. (2001). Human Resource Management. Fort Worth: Harcourt College Published.

Eko Suprayitno. (2005). Ekonomi Islam, Pendekatan Ekonomi Makro Islam dan Konvensional. Yogyakarta: Graha Ilmu.

Faustino Cardoso Gomes. (1995). Manajemen Sumber Daya Manusia. Yogyakarta: Andi Offset.

Justin G. Longenecker \& dkk. (2001). Kewirausahaan Manajemen Usaha Kecil Buku I. Jakarta: Salemba Empat.

Leonardus Saiman. (2009). Kewirausahaan Teori, Praktek dan Kasus-kasus. Jakarta : Salemba Empat.

Maihot Tua Effendi. (2002). Manajemen Sumber Daya Manusia. Jakarta: Grasindo.

Malayu S.P Hasibuan. (2007). Manajemen Sumber Daya Manusia. Jakarta : Bumi Aksara.

Michael Amstrong. (1994). Seri Pedoman Manajemen, Manajemen Sumber Daya Manusia. Jakarta: Gramedia.

Murti Sumarni dan Jonh Soeprihanto. (2000). Pengantar Bisnis. Yogyakarta: Liberty.

Sugiono. (2011). Metode Penelitian Kualitatif, Kuantitatif dan R\&D. Bandung: Alfabeta.

Sugiono. (2012). Metode Penelitian Pendidikan. Bandung: Alfabeta.

Veithzal Rivai. (2004). Manajemen Sumber Daya Manusia Untuk Perusahaan: Dari Teori ke Praktik. Jakarta: PT. Raja Grafindo Persada. 